\title{
SUSTAINED ANTHROPOGENIC IMPACT IN CARTER SALTPETER CAVE, CARTER COUNTY, TENNESSEE AND THE POTENTIAL EFFECTS ON MANGANESE CYCLING
}

\author{
Sarah K. Carmichael ${ }^{*}$, Mary J. Carmichael ${ }^{2,3}$, Amanda Strom², Krissy W. Johnson ${ }^{2}$, \\ Leigh Anne Roble ${ }^{1,4}$, Yongli GaO ${ }^{5,6}$, And Suzanna L. BräueR ${ }^{2}$
}

\begin{abstract}
Anthropogenic impact is a pervasive problem in heavily trafficked cave systems and fecal contamination is equally problematic in many cave and karst waters worldwide. Carter Saltpeter Cave in Carter County, Tennessee exhibits Mn(III/IV) oxide coatings associated with groundwater seeps, as well as manganese oxide growth on litter. Culturing results revealed that $\mathrm{Mn}(\mathrm{III} / \mathrm{IV})$ oxide production on litter was associated with $\mathrm{Mn}(\mathrm{II})$-oxidizing fungi. Immediately prior to this study, a massive $\mathrm{Mn}$ (II)-oxidizing biofilm bloomed at a cave seep. During the course of this study from 2009-2011, the seep exhibited a dramatic visual reduction in $\mathrm{Mn}(\mathrm{III} / \mathrm{IV})$ oxide production, which was hypothesized to correlate with a decrease in fecal nutrient input. Molecular methods (16S rRNA gene sequencing) confirmed the presence of Bacteroides-Prevotella human fecal indicators in this seep, and most probable number assays and ion chromatography of the associated seep water confirmed nutrient loading at the site. Further, phylogenetic analysis from clone sequences suggested a strong initial human-specific fecal signature (50\% of the sequences clustering with human feces sequences) in July 2009, and a weaker human signature (20\% clustering) by June 2011. Most Probable Number (MPN) analyses of heterotrophic bacteria at this site suggested that $\mathrm{Mn}$ (II) oxidation was correlated with heterotrophic activity, due to point source exogenous nutrient loading.
\end{abstract}

\section{INTRODUCTION}

Karst systems are vital sources of drinking water and support some of the most fragile and diverse ecosystems on Earth (van Beynen and Townsend, 2005). However, a combination of bedrock porosity and high hydrologic conductivity allow contaminants to penetrate limestone bedrock and move through karst conduit systems quickly, especially during periods of high velocity flow (Vesper et al., 2001). For this reason, karst hydrologic systems are often associated with channeled non-point source groundwater pollution (Green et al., 2006; Worthington, 2011).

It is not always possible to visually assess biological contamination in a karst or cave system. As a result, indirect methods of water monitoring for microbial contaminants are frequently employed by researchers: culture-based studies of water to detect coliform bacteria (Mikell et al., 1996; Rusterholtz and Mallory, 1994), molecular techniques to identify the presence/absence of fecal indicators and endemic species in karst systems (Ahmed et al., 2008; Johnson et al., 2011; Johnston et al., 2012; Porter, 2007; Roslev and Bukh, 2011), and the use of fluorescent dyetracers and microspheres to model water flow and pathogen dispersal in conduit systems (Goeppert and Goldscheider, 2011). Direct study of karst environments is restricted to open conduits that are large enough to allow for human movement and environmental manipulation. Thus, cave research has become a focal point in delineating the effects of anthropogenic impact on karst terrain.
As is the case with karst systems in general, anthropogenic impact in cave systems is a phenomenon that has been documented worldwide (Gillieson, 2011). Humaninduced alterations in the cave environment have been shown to destroy microhabitats (Northup, 2011), alter cave biogeochemical cycles, and impact sensitive cave fauna such as bats (Blehert et al., 2011). Any type of impact within caves is primarily manifested at the lower trophic levels, particularly in cave microbial communities that have the potential to exert powerful bottom-up controls on ecosystem health and stability (Horner-Devine et al., 2003). Due to the constancy of the cave environment, impact is quickly detrimental, and hard to reverse.

In 2009, a study was initiated to characterize the geomicrobiology of ferromanganese deposits in Carter Saltpeter Cave, Carter County, Tennessee (Carmichael et al., 2013). Human impact within the cave system was evident throughout the 2009-2011 study period and researchers often noted: 1) an abundance of graffiti

\footnotetext{
* Corresponding author: Appalachian State University Department of Geology, 572 Rivers Street, Rankin Science Building, Boone, NC 28608, carmichaelsk@appstate. edu

${ }^{1}$ Department of Geology, Appalachian State University, Boone, NC, 28608

${ }^{2}$ Department of Biology, Appalachian State University, Boone, NC, 28608

${ }^{3}$ Department of Biology, Wake Forest University, Winston-Salem, NC, 27109

${ }^{4}$ Department of Geology, University of Maryland, College Park, MD, 20742

${ }^{5}$ Department of Geosciences, East Tennessee State University, Johnson City, TN, 37614

${ }^{6}$ Department of Geological Sciences, University of Texas at San Antonio, San Antonio, TX, 78249
}

Journal of Cave and Karst Studies, December 2013•189 
Sustained anthropogenic impact in Carter Saltpeter Cave, Carter County, Tennessee and the potential effects on MANGANESE CYCLING

covering cave rocks and walls, 2) a prevalence of litter throughout the cave system, and 3) a distinct sewage odor present in some portions of the cave, some of which have active water flow. One of the water sources for the cave is known to be contaminated by a variety of inputs, including fecal coliforms (Gao et al., 2006), and many streams in this region are listed as impaired bodies of water (Johnson, 2002). At one of these sites, a thick, dark black, microbial biofilm was present in the water seeping from the cave wall and flowing onto the cave floor (Carmichael et al., 2013). The dark color of the seep was due to microcrystalline $\mathrm{Mn}$ (III/IV) oxide minerals, as detected with a Leucoberbelin Blue field test developed by Krumbein and Altmann (1973). Members of the Mountain Empire Grotto in Johnson City, Tennessee, suggested that the appearance of the biofilm coincided with a time in which a local septic tank company had been seen dumping raw sewage into a sinkhole that is hydrologically linked to the cave (John Matthews, personal communication). Additionally, early molecular microbiological analyses documented the presence of several dominant Operational Taxonomic Units (OTUs) in clone libraries constructed from biofilm material that were closely related ( $\geq 97 \%$ identical) to environmental clones isolated from fecal contaminated water and/or activated sludge (Carmichael et al., 2013), providing further circumstantial evidence of nutrient loading/sewage contamination at this site.

From 2009-2011, the appearance of the biofilm changed drastically, losing its dark black color, and exhibiting a dramatic visual reduction in $\mathrm{Mn}(\mathrm{III} / \mathrm{IV}$ ) oxide production, though estimated cells/g wet weight biofilm material remained relatively constant (Carmichael et al., 2013) and field tests continued to demonstrate the presence of microcrystalline Mn oxides, as detected using Leucoberbelin Blue (Krumbein and Altmann, 1973). Given the dramatic change in the appearance of the biofilm over the duration of the study and the molecular evidence of potential contamination, we hypothesized that the appearance and bloom of the biofilm was linked to an acute, point source nutrient loading event in an area hydrologically connected to this shallow cave system. Thus, we initiated this study to document the extent of human impact within the cave system, and to either validate or alleviate concern over potential fecal contamination at the site.

\section{Methods}

\section{Field Sites and Sample Collection}

Carter Saltpeter Cave (Fig. 1) is located in the Ordovician Knox Dolomite in Carter County, Tennessee. At a depth of approximately $30 \mathrm{~m}$, Carter Saltpeter Cave (CSPC) represents a relatively shallow epigenic cave system typical of those found within the southern Appalachian region. Environmental conditions within the dark zone of the cave are consistent with those found in other cave systems (Northup and Lavoie, 2001). A variety of carbonate speleothem formations occur throughout the cave system (e.g. flowstone, dripstone, soda straws, corrosion residue), and the cave is particularly enriched in ferromanganese deposits. The cave is located in close proximity to both agricultural land and residential areas, and during the time of this study the cave entrance was neither gated nor protected from human traffic. Daniel Boone Caverns (Fig. 1), located $53 \mathrm{~km}$ north of CSPC near Ft. Blackmore, Virginia, is also located in the Knox Dolomite, but is on an isolated and forested ridge and the entrance is gated and locked. While there are also ferromanganese deposits in Daniel Boone Caverns, there is no agricultural runoff infiltrating into the cave, nor is there evidence of significant human impact. For the purposes of this study, Daniel Boone Caverns is considered a geologic analogue of CSPC, as it shares the same host rock and has a similar climate and rainfall patterns; and therefore, is used as an intact control system to compare with the heavily impacted CSPC.

From 2009-2012, deposits from seeps and litter scattered throughout CSPC were screened for the presence of $\mathrm{Mn}$ oxides using $0.04 \%$ Leucoberbelin Blue (LBB), a redox indicator that is oxidized by $\mathrm{Mn}$ (III) or $\mathrm{Mn}$ (IV) to produce a bright blue color change (Krumbein and Altmann, 1973). Samples from seeps were collected aseptically by scraping the deposit coating down to the solid rock base using a sterile falcon tube. Care was taken to sample at locations within a deposit that tested LBBpositive for $\mathrm{Mn}(\mathrm{II})$ oxidation and to maximize the sampling of black/chocolate brown coatings in these locations. Samples were stored on ice, transported to the lab, and immediately processed for DNA extraction, electron microscopy, and/or culturing (Table 1).

DNA samples in this study were obtained from July 2009 to June 2011 in roughly three-six month intervals from two sites containing Mn(III/IV) oxides in CSPC (Fig. 1). The first site, Mn Falls, experienced a dramatic change in appearance over the course of one year (Fig. 2a and 2b). The water coming from the Mn Falls seep is hypothesized to be hydrologically connected to a sinkhole where there was an alleged sewage release from a septic tanker truck in 2008 (John Matthews, personal communication). Mud Trap Falls (Fig. 2c) is a second Mn(II)oxidizing community located approximately $30 \mathrm{~m}$ away from the Mn Falls seep. However, Mud Trap Falls is not hydrologically connected to Mn Falls and did not exhibit massive biofilm streamers, or other similar changes in appearance during this time. Therefore, Mud Trap Falls was selected as a comparison site. Water samples were also obtained from the Upper and Lower Shipwreck drip pools in Daniel Boone Caverns (Fig. 1) for comparison, as these water sources did not appear to have ferromanganese deposits associated with them. The temperature, $\mathrm{pH}$, and conductivity of the water at the Mn Falls seep and in the drip pools in Daniel Boone Caverns was measured using either a VWR SymPHony, Fisher Scientific accumet AP85 

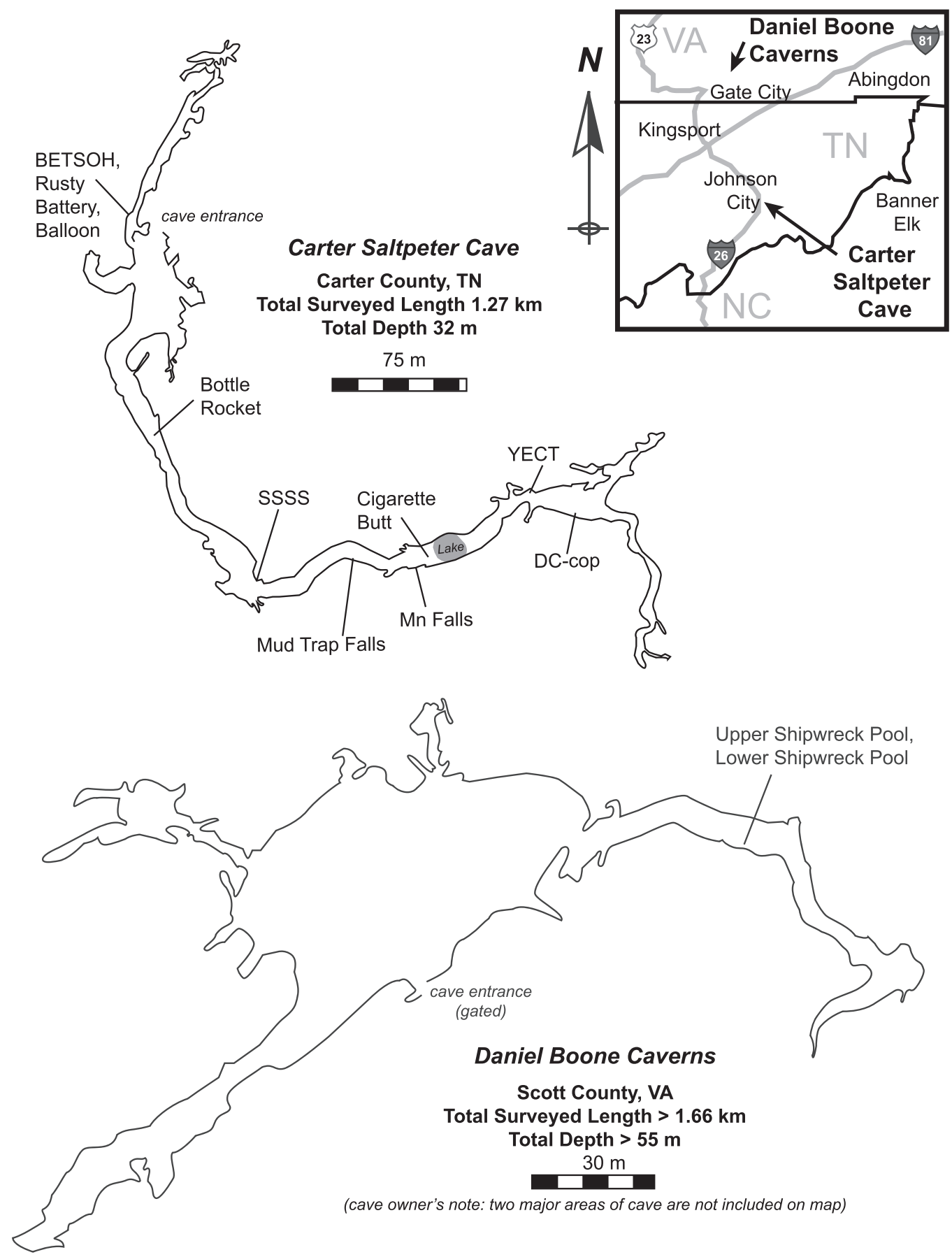

Figure 1. Maps of the Carter Saltpeter Cave (CSPC) and Daniel Boone Caverns, modified with arrows to indicate sampling locations. Regional map inset shows the relative location of the two cave systems within the upper Tennessee River Basin. Cave survey of CSPC conducted on February 8, 1981 by L. Adams, R. Knight, R. Page, and T. Wilson. Cave map drafted by L. Adams and adapted by S. Carmichael. Initial cave survey of Daniel Boone Caverns conducted in 1969 by M. Starnes, B. Lucas, D. Breeding, C. Stowers, and B. Balfour, and an additional survey was conducted from July-November 1996. Two substantial passages in the cave have not yet been surveyed. Cave map adapted by S. K. Carmichael.

Portable Waterproof $\mathrm{pH} /$ Conductivity Meter, or a YSI 556 MPS (Multiprobe System), then sampled via syringes and filtered through a $0.45 \mu \mathrm{m}$ micropore filter into sterilized Nalgene bottles and refrigerated.

\section{Geochemical and Mineralogical Analyses}

The anion concentrations in water from the Mn Falls seep and from drip pools in Daniel Boone Caverns were measured using a DionexICS-1600 Ion Chromatograph at

Journal of Cave and Karst Studies, December 2013•191 
Table 1. Descriptive summary of samples obtained from cave Mn(III/IV) oxide deposits in this study. Cave names are abbreviated as follows: Carter Saltpeter Cave (CSPC), Daniel Boone Caverns (DBC). See Figure 1 for locations of the individual samples. Analyses conducted are abbreviated as follows: Most probable number assays (MPNs), polymerase chain reaction (PCR), powder X-ray diffraction (XRD), single crystal micro X-ray diffraction ( $\mu$-XRD), Fourier Transform Infrared Spectroscopy (FT-IR), ion chromatography (IC), and electron microscopy (EM).

\begin{tabular}{|c|c|c|}
\hline Sample (Location) and Sample Type & Date Collected (mm/dd/yyyy) & Analyses Conducted \\
\hline Mn Falls (CSPC) & $\begin{array}{l}09 / 01 / 2009 \\
05 / 05 / 2010,06 / 30 / 2010\end{array}$ & $\begin{array}{l}\mu \text {-XRD (biofilm) } \\
\text { MPNs }\end{array}$ \\
\hline Mn(III/IV) oxide biofilm & $\begin{array}{c}\text { 07/04/2009, 07/31/2009, 01/15/2010 } \\
\text { 05/05/2010 09/14/2010, 10/05/2010 } \\
11 / 09 / 2010,05 / 16 / 2011,06 / 16 / 2011\end{array}$ & PCR with Bacteroides primers \\
\hline water & $\begin{array}{c}03 / 24 / 2010,05 / 05 / 2010,06 / 30 / 2010 \\
08 / 18 / 201010 / 05 / 2010,04 / 21 / 2011 \\
09 / 23 / 2011,09 / 06 / 2012,11 / 15 / 2012\end{array}$ & $\mathrm{IC}$ \\
\hline flowstone, mud substrate & 09/01/2009 & XRD, EM \\
\hline \multicolumn{3}{|l|}{ Mud Trap Falls (CSPC) } \\
\hline Mn(III/IV) oxide coating & $\begin{array}{l}\text { 07/04/2009, 07/31/2009, 01/15/2010, } \\
\text { 05/05/2010 06/30/2010, 09/14/2010 } \\
\text { 10/05/2010, 11/09/2010, 05/16/2011, } \\
\text { 06/16/2011 }\end{array}$ & PCR with Bacteroides primers \\
\hline & $01 / 152010,06 / 30 / 2010$ & MPNs \\
\hline & 09/10/2009 & $\mu-X R D$ (coating material) \\
\hline flowstone, mud substrate & $09 / 10 / 2009$ & XRD, EM \\
\hline $\begin{array}{l}\text { DC-cop (CSPC) } \\
\text { animal feces }\end{array}$ & $05 / 10 / 2010$ & Fungal cultures, XRD (substrate) \\
\hline SSSS (CSPC) & & \\
\hline cotton sock & $10 / 05 / 2010$ & Fungal cultures, EM \\
\hline YECT (CSPC) & & \\
\hline black electrical tape & $06 / 30 / 2010$ & $\begin{array}{l}\text { Fungal cultures, } \mu \text {-XRD (coating material, } \\
\text { cultures), EM, FT-IR (cultures) }\end{array}$ \\
\hline BETSOH (CSPC) & & \\
\hline black electrical tape & $09 / 06 / 2012$ & Fungal cultures \\
\hline $\begin{array}{l}\text { Bottle Rocket (CSPC) } \\
\text { fireworks }\end{array}$ & 09/06/2012 & Fungal cultures \\
\hline $\begin{array}{l}\text { Balloon (CSPC) } \\
\text { balloon }\end{array}$ & 09/06/2012 & Fungal cultures \\
\hline $\begin{array}{l}\text { Rusty Battery (CSPC) } \\
\text { rusty battery }\end{array}$ & 09/06/2012 & Fungal cultures \\
\hline $\begin{array}{l}\text { Upper Shipwreck Pool (DBC) } \\
\text { water }\end{array}$ & 07/18/2010, 09/22/2011, 10/14/2012 & $\mathrm{IC}$ \\
\hline $\begin{array}{l}\text { Lower Shipwreck Pool (DBC) } \\
\text { water }\end{array}$ & 07/18/2010, 09/22/2011, 10/14/2012 & $\mathrm{IC}$ \\
\hline
\end{tabular}

Appalachian State University. Characterization of the sampled substrate was performed on a Shimadzu $6000 \mathrm{X}$ ray Diffractometer (XRD) with ICDD PDF-4 Minerals software, and on a FEI Quanta 200 Environmental 192• Journal of Cave and Karst Studies, December 2013
Scanning Electron Microscope with an EDAX Si-Li energy dispersive spectrometer (ESEM-EDS). Identification of Mn oxide species was performed on a Rigaku D/Max Rapid micro-X-ray Diffractometer at the Smithsonian 

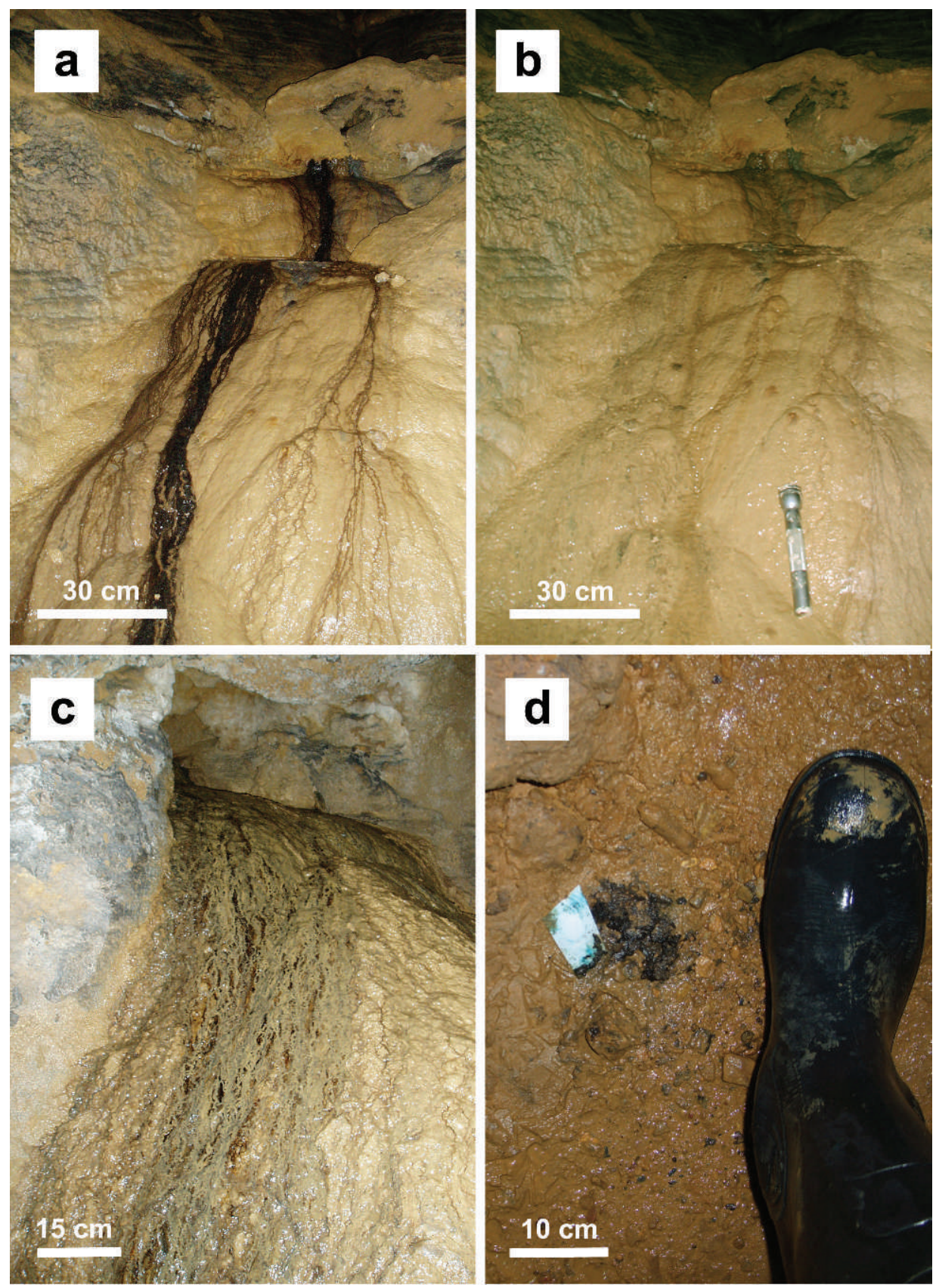

Figure 2. (a) Carter Saltpeter Cave (CSPC), Mn Falls site, July 2008, photo taken by Mountain Empire Grotto member John Matthews several months after a septic tanker truck may have released sewage into a local sinkhole. Image is published with permission. (b) CSPC, Mn Falls site, June 2010, Mn oxides reduced. Mn oxides have steadily decreased with time at the site since sampling began in July 2009. (c) CSPC, Mud Trap Falls site, July 2009. (d) LBB positive test (in bright blue on the filter paper) demonstrating the presence of Mn oxides on feces. Boot for scale. The surrounding clay tested LBB negative.

National Museum of Natural History, and via Fourier Transform Infrared Spectroscopy (FT-IR) using a KBr pellet press method with a Thermo Nicolet Magna 550 IR Spectrometer at Appalachian State University. FT-IR spectra were compared to Mn oxide reference spectra from Potter and Rossman (1979).
Detection of Human-Specific BaCteroidesPrevotella 16S rRNA Gene Sequences

DNA was extracted from cave samples using a bead beating protocol with the Fast DNA Spink Kit for Soil (MP Biomedicals, Solon, OH). The concentration of extracted DNA was determined using a NanoDrop ND-

Journal of Cave and Karst Studies, December 2013•193 
Sustained anthropogenic impact in Carter Saltpeter Cave, Carter County, Tennessee and the potential effects on MANGANESE CYCLING

1000 spectrophotometer (NanoDrop Technologies, Wilmington, DE). Human-specific Bacteroides-Prevotella 16S rRNA gene sequences were amplified from Mn Falls biofilm material using a primers designed by Bernhard and Field (2000a) with a demonstrated detection limit of $1.4 \times 10^{-6} \mathrm{~g}$ dry feces/liter. A nested PCR approach was utilized in an attempt to amplify the region of interest in DNA extracted from samples collected at Mud Trap Falls and Mn Falls between July 2009 and June 2011. Only two samples from Mn Falls amplified: July $2009(F)$ and June 2011 (4). Approximately $3 \mathrm{ng}$ of environmental DNA was used as a template for the first round of PCR amplification using the universal Bacteroides-Prevotella primers 32F (5'AACGCTAGCTACAGGCTT-3') and 708R (5'-CAATCGGAGTTCTTCGTG-3') (Bernhard and Field, 2000b). Each $50 \mu \mathrm{L}$ reaction contained 1.25 U AmpliTaq Gold (Applied Biosystems, Carlsbad, CA), $50 \mu \mathrm{M}$ each primer, 1X PCR Gold Buffer (Applied Biosystems, Carlsbad, CA), $2 \mathrm{mM} \mathrm{MgCl}_{2}$ Solution (Applied Biosystems, Carlsbad, CA), $200 \mu \mathrm{M}$ each dNTP, and 2X BSA (New England Biolabs, Ipswich, MA). An MJ Mini Personal Thermal Cycler (Bio-Rad, Hercules, CA) was used for all PCRamplification reactions. The amplification protocol for the first round of PCR is as follows: an initial denaturation of $94{ }^{\circ} \mathrm{C}$ for $5 \mathrm{~min}$, followed by 35 cycles of $94{ }^{\circ} \mathrm{C}$ for $30 \mathrm{~s}, 60$ ${ }^{\circ} \mathrm{C}$ for $1 \mathrm{~min}$, and $72{ }^{\circ} \mathrm{C}$ for $2 \mathrm{~min}$, followed by a final extension of $72{ }^{\circ} \mathrm{C}$ for $6 \mathrm{~min}$. PCR amplifications were conducted in triplicate to reduce individual PCR bias and visualized on a $1 \%$ agarose gel stained with GelRed Nucleic Acid Stain (Phenix Research, Candler, NC). A single positive band of approximately $700 \mathrm{bp}$ was visualized in DNA samples $F$ (July 2009) and 4 (June 2011) obtained from the Mn Falls biofilm. Replicate amplifications of each DNA template were pooled for downstream use in the next round of PCR.

One $\mu \mathrm{L}$ of PCR product from the pooled amplifications of either F (July 2009) or 4 (June 2011) DNA was used as a template for PCR amplification of human-specific Bacteroides-Prevotella $16 \mathrm{~S}$ rRNA gene sequences in the second round of the nested protocol. PCR amplification was conducted using the Bacteroides-Prevotella human-specific forward primer HF183 (5'- ATCATGAGTTCACATGTCCG-3') paired with the Bacteroides-Prevotella universal reverse primer 708R (5'-CAATCGGAGTTCTTCGTG-3') (Bernhard and Field, 2000a). Reaction conditions mimicked those given for the first round of the nested protocol, with the following adjustment in the amplification protocol: an initial denaturation of $94{ }^{\circ} \mathrm{C}$ for $5 \mathrm{~min}$, followed by 25 cycles of $94{ }^{\circ} \mathrm{C}$ for $30 \mathrm{~s}, 60^{\circ} \mathrm{C}$ for $1 \mathrm{~min}$, and $72{ }^{\circ} \mathrm{C}$ for $2 \mathrm{~min}$, followed by a final extension of $72{ }^{\circ} \mathrm{C}$ for $6 \mathrm{~min}$. Amplifications were conducted in triplicate to reduce individual PCR bias, and $5 \mu \mathrm{L}$ of PCR product for each template was visualized on a $1.5 \%$ agarose gel stained with GelRed Nucleic Acid Stain (Phenix Research, Candler, NC) to verify the presence of a ca. $600 \mathrm{bp}$ band. Amplifications of each PCR template were pooled and concentrated by rotary evaporation to a volume of approximately $10 \mu \mathrm{L}$. The concentrated PCR product for each template was run on a $1.5 \%$ agarose gel stained with GelRed Nucleic Acid Stain (Phenix Research, Candler, NC). A ca. 600 bp band for each template was manually excised from the gel and purified using an UltraCleanGelSpin DNA Extraction Kit (Mo-Bio Laboratories, Carlsbad, California). Purified PCR products of each DNA template were cloned into TOPO TA $p c r^{\circledR} 2.1$ vectors (Invitrogen, Carlsbad, CA), and plasmid DNA extracted from transformants using the QIAprep Spin Miniprep Kit (Qiagen, Valencia, CA) was screened using the M13F(-20) primer. Glycerol stocks were sequenced using the M13F $(-20)$ primer. Sequencing was conducted at BeckmanCoulter Genomics (Danvers, MA). OTUs were determined by DOTUR analysis (Schloss and Handelsman, 2005), and representative sequences for each OTU were chosen based on sequence length and quality. For phylogenetic analysis, additional sequences of interest were selected using ARB (Ludwig et al., 2004) and the NCBI taxonomic database (Johnson et al., 2008). OTU and additional sequences of interest were aligned using the on-line SILVA aligner (Pruesse et al., 2007). A phylogenetic tree (Figure 3) was constructed using the PHYLIP software package (Felsenstein, 2004) by conducting both neighbor-joining and maximum likelihood analysis. Clone sequences were deposited in GenBank under the accession numbers JN820135-JN820146.

\section{Most Probable Number Assays}

Most probable number (MPN) assays were employed to estimate the number of culturable heterotrophic microorganisms and heterotrophic $\mathrm{Mn}$ (II)-oxidizing microorganisms in CSPC (Table 3), as described previously (Bräuer et al., 2011; Johnson et al., 2012), with some modifications. Samples were collected from Mn Falls and Mud Trap Falls in January, May, and June of 2010 and stored overnight at $4^{\circ} \mathrm{C}$. A new media that we designed, FMO2 growth medium (Carmichael et al., 2013), was used for MPN assays. Samples were centrifuged to concentrate the wet biomass and the supernatant was removed. Samples were weighed and diluted 1:10 with medium. Serial dilutions of $1: 10$ diluted samples were made, ranging from $10^{-2}$ to $10^{-11}$ and inoculated in Cellstar 96 well culture plates (Greiner Bio-One, Monroe, NC). Each well contained $250 \mu \mathrm{L}$ sterile media and was inoculated with $25 \mu \mathrm{L}$ of either sample material, a positive control (Leptothrix sp.), or a negative control in eight replicates per sample. A control plate for each sample was inoculated and tested immediately for $\mathrm{Mn}$ (II) oxidation and heterotrophic metabolism using $50 \mu \mathrm{L} 0.04 \%$ LBB (rows 1-4) and $50 \mu \mathrm{L}$ $0.3 \%$ iodonitrotetrazolium chloride (INT) (Sigma Aldrich) (rows 5-8), respectively. Background level colorimetric results from the control plate test were recorded and used for comparison with the incubated plates. Plates were incubated in the dark at $10^{\circ} \mathrm{C}$ for 4 weeks (to mimic cave 

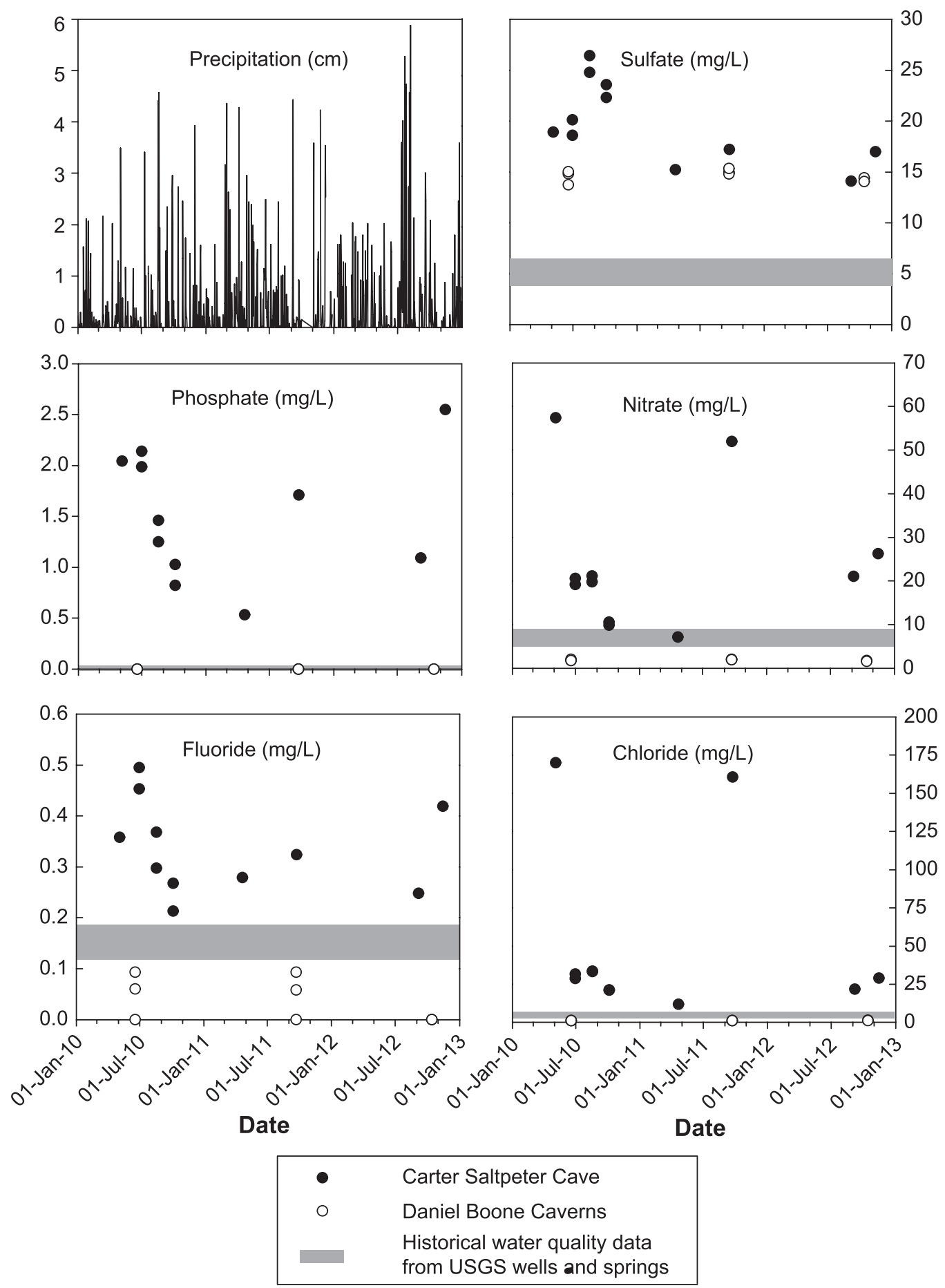

Figure 3. Ion chromatography results for water collected from Carter Saltpeter Cave (CPSC) Mn Falls seep, and from the upper and lower drip pools of Daniel Boone Caverns from May 2010-December 2012. Historical water quality data was collected by the United States Geological Survey in 1997-1998 from wells and springs in the Knox Dolomite located within $25 \mathrm{~km}$ of CSPC (data from USGS National Water Information System, http://nwis.waterdata.usgs.gov/usa/nwis/qwdata, accessed August 29, 2012) using sites USGS 03465770, USGS 03486175, and USGS 361726082181801. Precipitation data for Johnson City for the time covering the study were obtained from the National Climatic Data Center (http://www1.ncdc.noaa. gov/pub/orders/118435.csv, accessed January 8, 2013) using gauge GHCND:USC00404666. 
Sustained anthropogenic impact in Carter Saltpeter Cave, Carter County, Tennessee and the potential effects on MANGANESE CYCLING

Table 2. Field measurements of temperature, pH, conductivity, and dissolved oxygen for Mn Falls in Carter Saltpeter Cave (CSPC) and drip networks in Daniel Boone Caverns (DBC) at various dates from May 2010 to December 2013.

\begin{tabular}{|c|c|c|c|c|c|c|}
\hline Date & Cave & Temp., ${ }^{\circ} \mathrm{C}$ & $\mathrm{pH}$ & $\begin{array}{l}\text { Conductivity, } \\
\mu \mathrm{S} \mathrm{cm}\end{array}$ & $\mathrm{DO}, \mathrm{ppm}$ & Field Observations \\
\hline $05 / 05 / 2010^{\mathrm{a}}$ & CSPC & 13.1 & 7.00 & 436 & 8.2 & $\begin{array}{l}\text { water running clear, sampled from } \\
\text { water flowing into pool at base of seep }\end{array}$ \\
\hline $05 / 05 / 2010^{\mathrm{a}}$ & CSPC & 13.1 & 6.96 & 460 & 7.2 & $\begin{array}{l}\text { water running clear, sampled from } \\
\text { water running across flowstone in } \\
\text { middle of seep }\end{array}$ \\
\hline $06 / 30 / 2010^{\mathrm{b}}$ & CSPC & 13.9 & 7.44 & d & $\ldots$ & $\begin{array}{l}\text { sampled from water flowing into pool at } \\
\text { base of seep; cave floor damp to dry }\end{array}$ \\
\hline $06 / 30 / 2010^{\mathrm{b}}$ & CSPC & 15.7 & 7.47 & d & $\ldots$ & $\begin{array}{l}\text { sampled from stagnant pool at base of } \\
\text { seep; cave floor damp to dry }\end{array}$ \\
\hline $04 / 21 / 2011^{\mathrm{b}}$ & CSPC & 13.4 & 8.51 & 523 & $\ldots$ & $\begin{array}{l}\text { sampled from middle of seep, water } \\
\text { running over flowstone; cave floor } \\
\text { very wet }\end{array}$ \\
\hline $09 / 23 / 2011^{\mathrm{b}}$ & CSPC & 13.1 & 8.03 & 737 & $\cdots$ & $\begin{array}{l}\text { sampled from water flowing into pool at } \\
\text { base of seep }\end{array}$ \\
\hline $09 / 06 / 2012^{\mathrm{b}}$ & CSPC & 13.4 & 8.44 & 677 & $\cdots$ & $\begin{array}{l}\text { sampled from middle of seep, cave floor } \\
\text { damp }\end{array}$ \\
\hline $11 / 15 / 2012^{\mathrm{b}}$ & CSPC & 13.1 & 7.64 & d & $\ldots$ & sampled from top of seep, cave floor dry \\
\hline $07 / 28 / 2011^{\mathrm{b}}$ & $\mathrm{DBC}$ & $\mathrm{d}$ & 8.07 & 483 & $\ldots$ & upper pool \\
\hline $07 / 28 / 2011^{\mathrm{b}}$ & $\mathrm{DBC}$ & d & 8.06 & 428 & $\ldots$ & lower pool \\
\hline $09 / 22 / 2011^{\mathrm{b}}$ & $\mathrm{DBC}$ & 12.2 & 8.02 & 354 & $\ldots$ & upper pool \\
\hline $09 / 22 / 2011^{\mathrm{b}}$ & $\mathrm{DBC}$ & 11.8 & 8.34 & 352 & $\ldots$ & lower pool \\
\hline $10 / 14 / 2012^{\mathrm{c}}$ & $\mathrm{DBC}$ & 11.8 & 7.87 & 327 & 11.5 & upper pool \\
\hline $10 / 14 / 2012^{\mathrm{c}}$ & $\mathrm{DBC}$ & 11.7 & 7.97 & 321 & 10.2 & lower pool \\
\hline
\end{tabular}

conditions) and scored immediately using LBB and INT as described above. Plates were then returned to the dark at $10^{\circ} \mathrm{C}$ and allowed to incubate overnight to note additional color change, if any. MPN assays were scored again after 24 hours, with no notable change in results being observed. Results were applied to Curiale's freeware MPN calculator (accessed at http://www.i2workout.com/mcuriale/mpn/index.html) to estimate the total number of culturable heterotrophic microorganisms and culturable heterotrophic $\mathrm{Mn}(\mathrm{II})$-oxidizing microorganisms in cave samples.

\section{Culturing of Fungi From Litter}

Fungal culture enrichments were obtained using litter that tested LBB-positive in the cave. Litter was swiped on plates containing an AY (Santelli et al., 2011) agarsolidified media. The plated cultures were tested for $\mathrm{Mn}(\mathrm{II})$-oxidation via LBB colorimetric assay. To discourage contamination by other fungi and bacteria, all $\mathrm{Mn}$ (II)oxidizing fungal samples were recultured on fresh media at least three times using a stab and swipe method. Several samples (YECT Stab 1 and SSSS) were maintained on media containing Ampicillin to prevent bacterial contam- ination. Samples were incubated in the dark at room temperature for 2-6 weeks.

\section{Electron And Light Microscopy of \\ Fungal Cultures}

Light microscopy of fungal cultures grown on AY media was performed using an Olympus SZX12 Zoom Stereo Microscope with a Sony HDR-HC7 HDV video camcorder. For transmission electron microscopy with energy dispersive X-ray spectroscopy (TEM-EDS) and for element mapping via scanning transmission electron microscopy (STEM), samples were mounted on Carbon Type B formvar-coated copper 200 mesh grids (Ted Pella, Inc.), air dried, carbon coated, and analyzed using a JEOL JEM-1400 TEM with a G-135 Pentafet Sealed Window Xray detector at $80 \mathrm{kV}$ and/or $120 \mathrm{kV}$ in the Dewel Microscopy Facility at Appalachian State University.

Environmental scanning electron microscopy with energy dispersive X-ray spectroscopy (ESEM-EDS) was performed on a FEI Quanta 200 Environmental SEM with an EDAX Si-Li EDS detector in the Dewel Microscopy Facility at Appalachian State University. Portions of 
S.K. Carmichael, M.J. Carmichael, A. Strom, K.W. Johnson, L.A. Roble, Y. Gao, and S.L. Bräuer

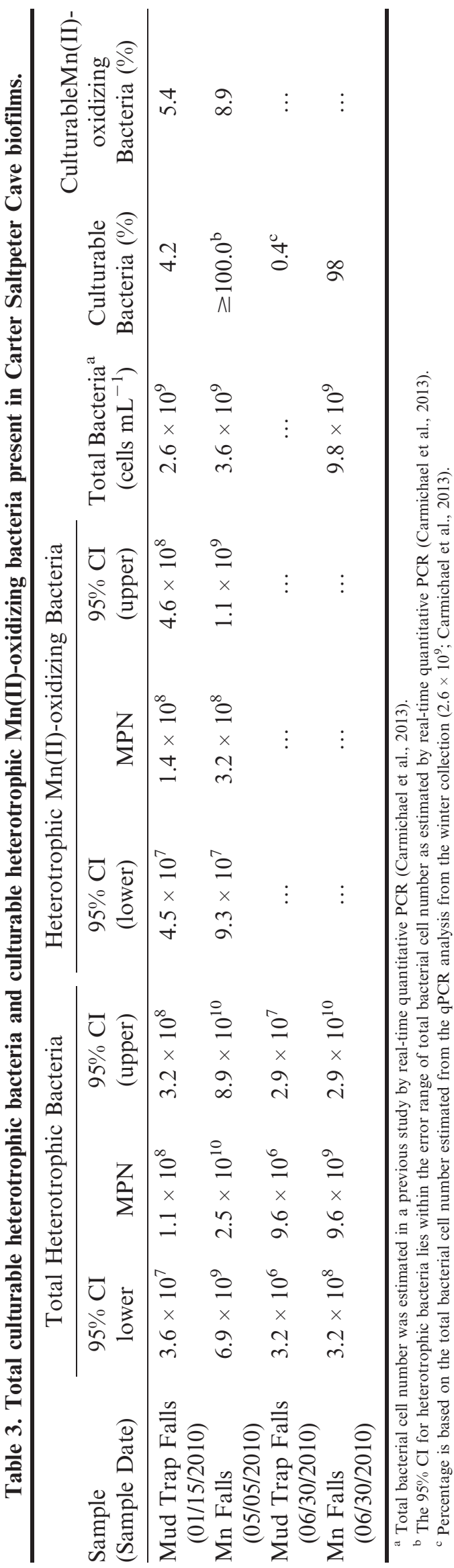

fungal growth from AY stab cultures were transferred onto a piece of carbon tape and mounted on a $13 \mathrm{~mm}$ aluminum stub and run under low vacuum conditions between 15 and $20 \mathrm{kV}$, with a $5 \mu \mathrm{m}$ beam spot size.

\section{Results}

\section{Geochemistry and Mineralogy}

Measurements of temperature, $\mathrm{pH}$, dissolved oxygen, and conductivity were conducted in the field (Table 2). Temperatures ranged from $13-15^{\circ} \mathrm{C}, \mathrm{pH}$ from 7.4-8.0, and conductivity from 436-737 $\mu \mathrm{S} / \mathrm{cm}$. Higher conductivities were associated with a shallow ( $5 \mathrm{~cm}$ deep) pool at the base of the Mn Falls seep, which contained significant fine sediment. IC analyses of phosphate, nitrate, sulfate, fluoride, and chloride for Mn Falls from 2010-2011 all demonstrated variable but significantly higher values of these anions in comparison to water from Daniel Boone Caverns and water from nearby wells and springs, and these variations did not appear to be correlated with precipitation patterns (Fig. 3).

SEM-EDS and XRD measurements indicate that the substrate for both Mn Falls and Mud Trap Falls consists of a mixture of nontronite clay and calcite. Bacterial Mn(III/IV) oxides at both Mud Trap Falls and Mn Falls were tentatively identified via single crystal micro-XRD as poorly crystalline buserite, a Na-rich layered phase in the birnessite group (Post, 1999) with broad peaks indicating the presence of 9.5-7.3 $\AA$ sheets. FT-IR analysis of cultured fungi from electrical tape contained a broad absorbance peak from $3700-3200 \mathrm{~cm}^{-1}$, indicating $\mathrm{O}-\mathrm{H}$ bonds, and additional sharper peaks associated with $\mathrm{Mn}$ oxide octahedral bonds at approximately 1631, 727, 530, $470 \mathrm{~cm}^{-1}$. Peaks associated with amines and polysaccharides were also present. This pattern indicates that disordered todorokite, a Ca-rich mineral with a tunnel structure, may be the dominant Mn(III/IV) oxide present, although poorly crystalline todorokite and birnessite group minerals do frequently coexist in biologically produced $\mathrm{Mn}(\mathrm{III} / \mathrm{IV})$ oxides, as the biological formation of either layer or tunnel structures is dependent on local solution chemistry (Zhu et al., 2010). Regardless, the Mn(III/IV) oxides described in this study are $\mathrm{nm}$ scale and poorly crystalline; and therefore, cannot be definitively determined using traditional powder X-ray and electron diffraction techniques. Our findings are consistent with observations of biologically produced $\mathrm{Mn}$ (III/IV) oxides in previous studies (Spiro et al., 2010, and references therein).

\section{Detection of Human-Specific BaCteroides- Prevotella 16S rRNA Gene Sequences}

A molecular-based survey of the Mn Falls site was initiated to detect the presence or absence of human fecal indicators in DNA extracted from the biofilm from 20092011. A primer set designed by Bernhard and Field (2000a; 2000b) targeting human-specific Bacteroides-Prevotella was 
Sustained anthropogenic impact in Carter Saltpeter Cave, Carter County, Tennessee and the potential effects on MANGANESE CYCLING

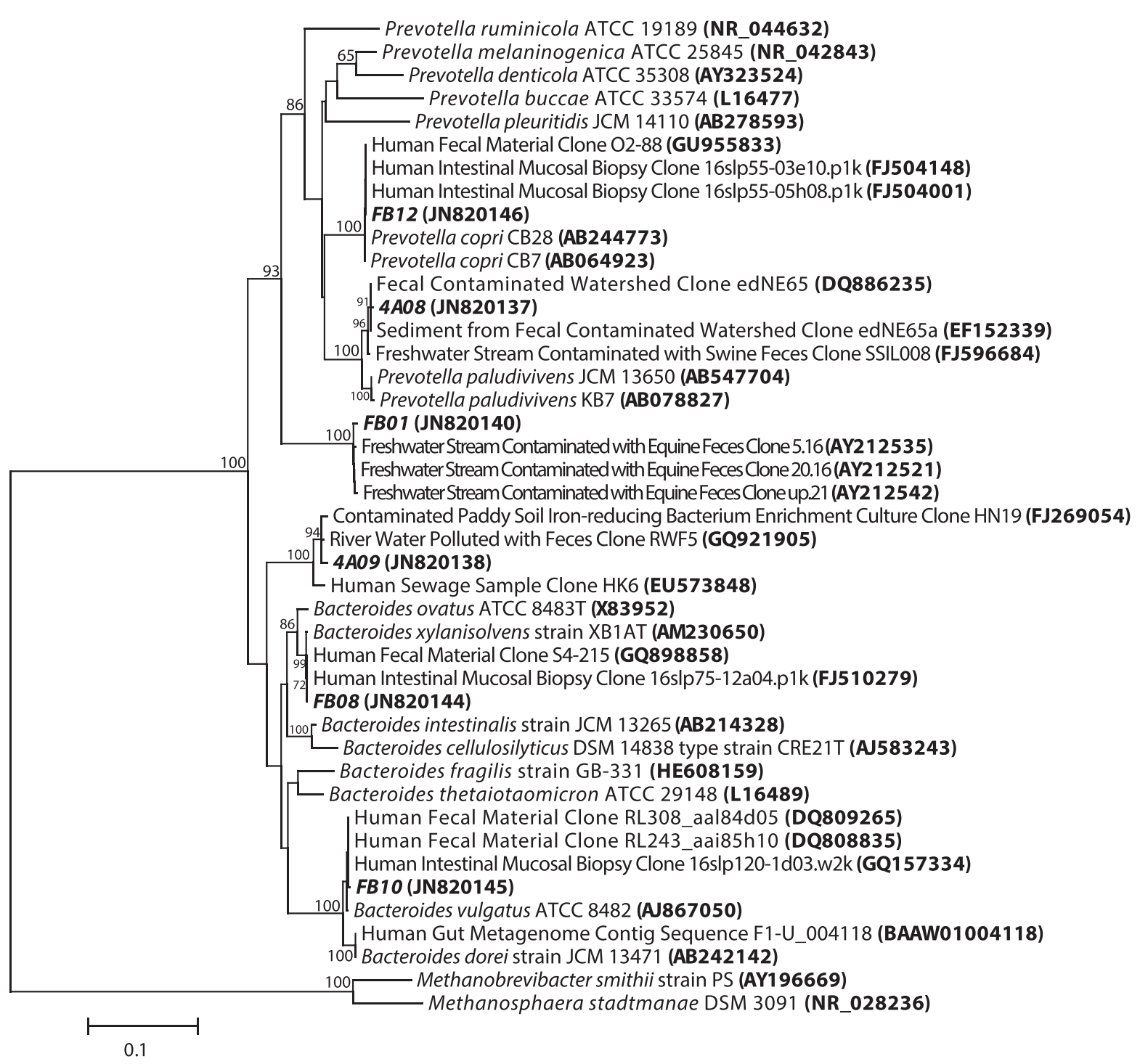

Prevotellaceae

Bacteroidaceae

Figure 4. Neighbor-joining tree inferring the phylogenetic placement of SSU rRNA gene sequences obtained from the Mn Falls biofilm found in Carter Saltpeter Cave (CSPC) in this study in either July 2009 (sequences beginning with $F$ ) or June 2011 (sequences beginning with 4). Alignments were created using the on-line SILVA aligner. Dendogram was created using PHYLIP. Bootstrapping values are shown for nodes that were supported $>\mathbf{5 0} \%$ of the time with maximum-likelihood analysis (data not shown). Methanobrevibacter smithii and Methanosphaera stadtmanae were used as outgroups. Branch lengths indicate the expected number of changes per sequence position (see scale bar).

chosen due to its sensitivity and reliability according to previous reports in the literature (Ahmed et al., 2009a; 2009b). Multiple attempts at amplification of DNA extracted from both Mn Falls and Mud Trap Falls samples across multiple collection dates approximately every 36 months from 2009-2011 (Table 1) resulted in only two positive amplifications. Both were from Mn Falls: sample $F$, extracted in July 2009 during an initial sampling trip to the cave when the biofilm was in bloom (OTUs from this extraction are prefaced by an $F$ in Figure 4), and sample 4, extracted in June 2011 during a more recent sampling trip to the cave when the biofilm was drastically reduced in appearance (OTUs from this extraction are prefaced by a 4 in Figure 4). Multiple attempts at amplification of DNA extracted from Mud Trap Falls were unsuccessful. Clones were binned into OTUs for phylogenetic analysis using a 99\% cutoff. Results revealed 6 unique OTUs (Fig. 4) out of ca. 15 total sequences.

Three OTUs (FB12, 4A08, and FB01) clustered within the Prevotella spp. (Fig. 4), a genus that is commonly isolated from the oral cavity, upper respiratory tract, and urogenital tract of humans (Shah and Collins, 1990). Clone FB12 shared $100 \%$ identity over a ca. 700 bp read to a clone isolated from a study of the microbiota of the human intestine (Walker et al., 2011), and 99\% identity to clones isolated from the human gut (Hayashi et al., 2002). FB12's 
closest cultured relative was Prevotella copri, the type strain of which was isolated from human feces (Hayashi et al., 2007). Clone $4 A 08$ shared $99 \%$ identity to environmental clones isolated from fecal contaminated watersheds (Lamendella et al., 2007; 2009), and 97\% identity to its closest cultured relative, Prevotella paludivivens, a species isolated from rice-plant residue (Ueki et al., 2007). Clone FB01 shared $99 \%$ identity to environmental clones isolated from equine-fecal contaminated water (Simpson et al., 2004).

The three remaining OTUs (Fig. 4), 4A09, FB08, and $F B 10$, represented sequences that are members of the Bacteroides spp., a genus commonly isolated from the mammalian gastrointestinal tract (Shah and Collins, 1990). Clone $4 A 09$ shared $98 \%$ identity over a ca. $700 \mathrm{bp}$ read to environmental clones isolated from river water polluted with feces (Ju-Yong et al., 2010) and human sewage samples (Dorai-Raj et al., 2009). Clone FB08 shared 100\% identity to clones isolated from the human intestine (Walker et al., 2011) and human feces. Clone FB10 shared $99 \%$ identity to clones isolated from the human intestine and human feces in a study investigating the association of human gut microbial ecology with obesity (Ley et al., 2005).

Molecular evidence from this study indicates the presence of a Bacteroides-Prevotella fecal signature in DNA extracted from the Mn Falls biofilm in July 2009 and June 2011. Phylogenetic analysis from clone sequences suggests a stronger human-specific signature in July 2009, with $50 \%$ of the sequences clustering with sequences from human feces, a conclusion that is consistent with the hypothesis of sewage contamination localized at this site within the cave. A weaker human signature, as defined by a lower percentage of sequences $(20 \%)$ clustering with sequences from human feces, was detected in the June 2011 sample of Mn Falls.

\section{Most Probable Number Assays}

Most probable number (MPN) assays of total culturable heterotrophic bacteria and total culturable heterotrophic Mn(II)-oxidizers at Mn Falls and Mud Trap Falls were conducted on samples obtained on three different occasions, January 2010 (Mud Trap Falls), May 2010 (Mn Falls), and June 2010 (Mn Falls and Mud Trap Falls) (Table 3). Cultivation-based enumeration of heterotrophic $\mathrm{Mn}(\mathrm{II})$-oxidizing bacteria revealed no significant differences between population numbers at Mud Trap and Mn Falls.

Results from cultivation-based enumeration of total heterotrophic bacteria revealed an interesting trend (Table 3), however. Data from the January 2010 sampling of Mud Trap Falls indicated an average count of $1.1 \times 10^{8}$ cells/g wet weight; data from the May 2010 sampling of Mn Falls indicated an average count of $2.5 \times 10^{10}$ cells/g wet weight. No overlap in $95 \%$ confidence intervals was observed between these two samples, which is indicative of a significant difference in total culturable heterotrophic bacteria between these two sites.
June 2010 data from both sites reflects the same pattern, with an average count of $9.6 \times 10^{6}$ cells/g wet weight at Mud Trap Falls and $9.6 \times 10^{9}$ cells/g wet weight at Mn Falls. The difference between the two sites in June 2010 data is more pronounced, as total cultivable heterotrophic bacteria at $\mathrm{Mn}$ Falls outnumbered Mud Trap falls by three orders of magnitude, with no overlap observed in $95 \%$ confidence intervals. An observed increase in the total culturable heterotrophic bacteria at the Mn Falls site is suggestive of greater nutrient loading at this site. A slight overlap was observed between the $95 \%$ upper confidence interval at Mud Trap Falls in January 2010 and the 95\% lower confidence interval at Mn Falls in June 2010. However, the percent of culturable heterotrophic bacteria, within the total population estimated using qPCR, was consistently higher (approaching $100 \%$ ) at Mn Falls (Table 3), a finding that is supportive of nutrient loading at the Mn Falls site.

\section{Mn(II) Oxidation Associated With Litter}

Field observations indicated distinct increases in microbial $\mathrm{Mn}(\mathrm{II})$ oxidation in response to nutrient input. Field samples unintentionally amended with litter or feces became encased in a slimy $\mathrm{Mn}$ (III/IV) oxide coating, examples of which included an abandoned sock, a corroding battery, cigarette remains, electrical tape, fireworks, balloons, and feces from a small herbivorous mammal (Fig. 2d). In an effort to better characterize the responsible organisms, culturing experiments on the litter produced a variety of $\mathrm{Mn}(\mathrm{II})$-oxidizing fungal species (Fig. 5), many of which have not yet been described in the literature and whose phylogenetic associations are still uncertain. Scanning and transmission electron microscopy of these fungi have shown that $\mathrm{Mn}$ is sequestered in spores, and/or along hyphal junctions and septa (Fig. 5e, 5f).

\section{DisCUSSION}

Karst aquifers and deep cave systems with minimal human impact are considered to be oligotrophic environments, defined by less than $2 \mathrm{mg}$ total organic carbon per liter (Barton and Jurado, 2007), and several nutrients such as nitrogen, sulfur, phosphorous, and iron are considered to be additional limiting factors in these systems (Goldscheider et al., 2006). Microbial species within pristine caves (those that have little or minimal human impact) are adapted to leading an oligotrophic lifestyle (Northup et al., 2003). However, gut-related microbiota, which are generally not endogenous members of the cave microflora, are adapted to environments containing high levels of carbon and other nutrients (Ley et al. 2006). Therefore, it is reasonable to hypothesize that sites within cave systems that experience impact from sewage/nutrient loading would demonstrate higher culturable heterotrophic cell counts than areas without impact. There was no significant difference between the total bacterial number estimated 

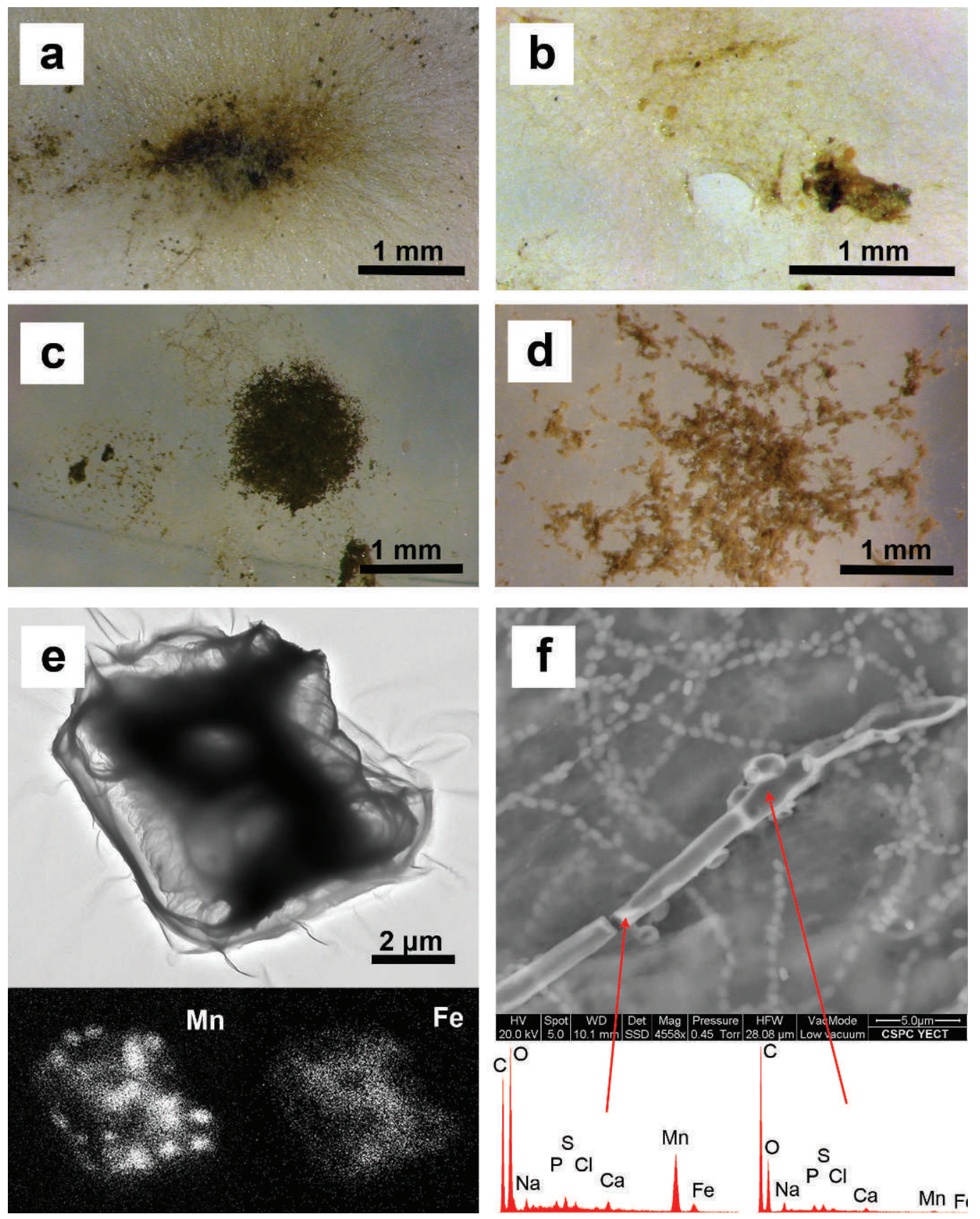

Figure 5. Light microscopy of Mn (II)-oxidizing fungi from Carter Saltpeter Cave on AY agar-solidified media, cultured from electrical tape (a), fireworks (b), an abandoned sock (c), and a rusty battery (d). Scanning transmission electron microscopy of fungi cultured from the abandoned sock indicates the presence of Mn and Fe within fungal spores (e). Backscattered scanning electron microscopy imaging of fungi cultured from electrical tape indicates elevated levels of Mn within hyphal junctions, but minimal Mn content within the hyphal interiors (f).

using qPCR in a separate study (Carmichael et al., 2013) and total culturable heterotrophic bacteria estimated using MPN analyses at the Mn Falls site on the June 2010 sampling date, indicating that a large number of the bacteria present at the site were culturable.

Significantly higher average cultivable cell counts and consistently higher percentages of culturable bacteria at the Mn Falls site relative to Mud Trap Falls support the 200 • Journal of Cave and Karst Studies, December 2013 hypothesis of localized nutrient loading/sewage contamination at the Mn Falls site in CSPC. This hypothesis is bolstered by several field studies investigating nutrient loading in caves via tourism (Ikner et al., 2007), septic effluent (Simon and Buikema, 1997), and input of rich carbon sources such as guano, feces, and human traffic (Mulec et al., 2012) where, in all three studies, cultivable counts of bacteria (either total CFUs, total aerobic 
bacteria, or total fecal coliform bacteria), were at least two orders of magnitude higher than similar counts in low impact zones within the caves. Experimental manipulations of soil plots have also revealed an increase in bacterial biomass within plots fertilized by feces or a combination of lint and feces relative to plots fertilized with lint alone or control plots (Chelius et al., 2009), findings which support our hypothesis that the bloom of biofilm material and increase in culturable numbers of bacteria at Mn Falls were likely due to nutrient-loading at this site.

It is important to note that cultivation-based experiments are inherently biased by media design and inoculation/incubation techniques (Rusterholtz and Mallory, 1994), and that dilution of fecal matter, which would occur within karst conduit systems, does affect the ability to culture and detect fecal indicator bacteria in environmental samples (Ahmed et al., 2008b). The present study addresses this bias via molecular-based characterization of the Mn Falls microbial community. Molecular surveys demonstrated the presence of a Bacteroides-Prevotella fecal signature in DNA extracted from the Mn Falls biofilm in both July 2009 and June 2011, with a stronger human signature detected in the July 2009 sample. Bacteroides spp. represents a prominent new alternative indicator for the detection of fecal pollution in environmental samples due to an inability to survive in a non-host environment for lengthy periods of time, a strict association with warmblooded animals, and a relative abundance of members of this genus in fecal samples as compared to traditional indicators (Ahmed et al., 2008a). Molecular-based methods have also been successfully employed in other studies to detect the presence of human fecal indicators in karst aquifers (Johnson et al., 2011; Reischer et al., 2007) and human impact in caves (Johnston et al., 2012).

Water chemistry from Mn Falls also points to point source nutrient loading via septic effluent. Field tests $\mathrm{pH}$, conductivity, etc.) revealed values for CSPC that were consistent with those reported from other caves and local springs contaminated with fecal indicators (Johnson et al., 2011; Simon and Buikema, 1997). Elevations in septicassociated chemicals including chloride, fluoride, and phosphate strongly suggest the presence of septic input from 2010 to 2011 (Fig. 3). Chloride and phosphate are commonly associated with septic effluent, and chloride is often used as a tracer for septic plumes (Denver, 1989; Minnesota Pollution Control Agency, 1999; Robertson et al., 1998). Fluoride concentrations, while highly variable, may also be elevated quite significantly (Minnesota Pollution Control Agency, 1999). Naturally occurring elevated fluoride levels are unlikely, as fluorite is not abundant in the surrounding bedrock (Hoagland et al., 1965 ) and is not soluble at $\mathrm{pH}$ values $<8$ in the presence of calcite (Miller and Hiskey, 1972). In addition, Johnson City (located less than four miles to the northwest) fluoridates their municipal water to attain values $1 \mathrm{mg} / \mathrm{L}$ (Washington County Water and Sewer Department, personal communication), which also points to septic effluent as a likely source of high fluorine levels in the seep. Further, CSPC is located in an active conduit system, which would be consistent with relatively rapid changes in water chemistry. Sulfate and nitrate are also variable yet elevated with respect to pristine cave waters and local well and spring waters. The proximity of the USGS wells and springs to CSPC make these elevations unlikely to be the result of land use differences. The elevated levels of nutrients (particularly fluoride) that remain in the water may be due to continued flushing of the conduit leading to the seep rather than continuous sewage input, which would have been detected via MPN analyses and gene sequencing.

Although it is difficult to visually assess changes in microbial diversity in response to eutrophication or other disturbances directly in the field, changes in function are easily seen among $\mathrm{Mn}$ and $\mathrm{Fe}$ oxidizing microbial communities, where such changes are visible as a significant alteration in the abundance of metal oxide produced. The Mn Falls bloom, with an associated distinct fecal odor, appeared in 2008, and both have slowly disappeared over the course of the study (Fig. 2). Several mechanisms of heterotrophic $\mathrm{Mn}(\mathrm{II})$ oxidation have been proposed. Bacteria such as Pseudomonas putida GB-1 (Geszvain et al. 2013), various species of Bacilli (Francis and Tebo, 2002), and Leptothrix discophora SS-1 (Corstjens et al. 1997) are all thought to use multicopper oxidases for $\mathrm{Mn}(\mathrm{II})$ oxidation. Whereas the bacteria Aurantimonas maganoxydans SI85-9A1 and Erythrobacter sp. strain SD21 are thought to use a manganese-oxidizing peroxidase (Anderson et al. 2009). Similarly, fungi of the Basidiomycetes are known to use a manganese peroxidase enzyme (Liers et al. 2011) to oxidize Mn (II). MPN analyses in this study, however, suggest that $\mathrm{Mn}$ (II)-oxidation at this site was most likely correlated with heterotrophic activity, an idea consistent with one that has recently emerged in the geomicrobiological and geochemical literature: that $\mathrm{Mn}$ (II)-oxidation can be affiliated with reactive oxygen species (ROS) production by both heterotrophic bacteria and fungi. For example, Learman et al. (2011) reported that Roseobacter oxidizes $\mathrm{Mn}$ (II) indirectly via ROS that are most likely generated as a normal part of electron transport during aerobic, heterotrophic respiration. In addition, Hansel et al. (2012) have shown that Stilbella aciculosa, an Ascomycete fungus, oxidizes $\mathrm{Mn}$ (II) via extracellular ROS produced during asexual reproduction. Heterotrophic $\mathrm{Mn}(\mathrm{II})$-oxidation associated with ROS production also makes sense thermodynamically, since the first electron transfer in the oxidation of $\mathrm{Mn}$ (II) to $\mathrm{Mn}$ (III/IV) was demonstrated to be a rate limiting step, whereas $\mathrm{Mn}$ (II)oxidation by superoxide, hydrogen peroxide or a hydroxyl radical were shown to be favored reactions (Luther, 2010).

Although previous studies have indicated that Mn(III/ IV) oxide production in the CSPC groundwater seeps was primarily associated with $\mathrm{Mn}(\mathrm{II})$-oxidizing bacteria

Journal of Cave and Karst Studies, December 2013 201 
(Carmichael et al., 2013), culturing results in this study revealed that $\mathrm{Mn}(\mathrm{III} / \mathrm{IV})$ oxide production on litter was associated with Mn(II)-oxidizing fungi (Fig. 5). Rapid fungal $\mathrm{Mn}(\mathrm{III} / \mathrm{IV})$ oxidation of feces and litter (including a balloon, fireworks, a discarded sock, electrical tape, and a battery) over the course of several weeks also supported heterotrophic growth in a nutrient-limited cave environment.

Although there was a dramatic (albeit gradual) visual reduction in $\mathrm{Mn}$ oxide production during sampling trips from 2009-2011 (Fig. 2a, 2b), minor amounts of Mn oxides continued to be produced during this time, as shown by LBB testing. The reasons for this reduction are not entirely clear, but dissolution of birnessite group structures by siderophores (chelating agents) in microbial secretion and/or membranes, as demonstrated for Shewanella oneidensis (Duckworth and Sposito, 2007; Fischer et al., 2008), is a possible mechanism to reduce the presence of birnessite group Mn oxides. Poorly crystalline buserites (Na-rich birnessites) were identified in the biofilm at $\mathrm{Mn}$ Falls in this study, and $\mathrm{Mn}(\mathrm{II})$-oxidizing bacteria are known to produce poorly crystalline birnessite group minerals (Spiro et al., 2010 and references therein), which is consistent with siderophore dissolution of $\mathrm{Mn}$ oxides in the Mn Falls biofilm. Other chemical factors such as $\mathrm{pH}$, redox potential, or concentrations of nutrients or $\mathrm{Mn}$ (II) may also have played a role.

\section{Conclusions}

Multiple techniques including molecular, chemical, and culture-based analyses conducted over a three-year extended study have provided evidence of sustained anthropogenic impact within the Carter Saltpeter Cave system. Our study has provided compelling field data in support of the hypothesis that $\mathrm{Mn}$ (II)-oxidation can be associated with both bacterial and fungal heterotrophic activity, which in this case, was most likely stimulated in response to point source exogenous nutrient loading.

Due to the inherent stability of the cave environment and the highly adapted cave macro- and microfauna, this type of anthropogenic impact has the potential to disrupt the delicate balance of life within a cave and exert a strong negative effect on ecosystem function. Localized variations in geochemistry and nutrient availability have been shown to impact microbial community structure (Johnston et al., 2012; Barton and Jurado, 2007; Shabarova and Pernthaler, 2010) and niche diversification (Engel et al., 2010; Macalady et al., 2008). Further, the composition of cave microbial communities mediates and stabilizes biogeochemical cycling and mineralization processes within an environment (Portillo and Gonzalez, 2010; Portillo et al., 2009).

Legal protection for cave and karst systems exists at the Federal and State levels, although enacted legislation varies in the degree of protection and is often wrought with loopholes (van Beynen and Townsend, 2005). The effectiveness of legislation, guidelines, recommendations, and management plans is contingent on the accumulation of high quality baseline data that delineates the sources of contamination within a system and on the documentation of specific impacts within a cave or karst system (Northup, 2011). Clearly, there is a continued need for research, especially in regions such as the Appalachians, where cave density is high and research in cave systems is lacking.

\section{ACKNOWLEDGEMENTS}

The authors would like to thank Taylor Burnham, Jared Butler, Ashley Hawkins, Seth Hewitt, Daniel Parker, Oliver Burns, Cameron Bachelor, and Bryan Zorn for their help with sample collection and field/laboratory assistance, and to Guichuan Hou, Clara Chan, and Chuanhui $\mathrm{Gu}$ for assistance with electron microscopy and IC analyses of cave waters. Jeffrey Post and Cara Santelli in the Mineral Sciences Department at the Smithsonian National Museum of Natural History performed Mn oxide identification. We are appreciative of the landowners of Carter Saltpeter Cave and Daniel Boone Caverns for site access. Partial support was provided through National Science Foundation grant 0935270 awarded to S.L. Bräuer, two grants from the North Carolina Space Grant New Investigators Awards to S.K. Carmichael and S.L Bräuer, and through a North Carolina Space Grant Graduate Research Fellowship awarded to M.J. Carmichael. Support was also provided by Appalachian State University's Office of Student Research and University Research Council. We are grateful to two anonymous reviewers who provided helpful comments on this paper.

\section{REFERENCES}

Ahmed, W., Goonetilleke, A., and Gardner, T., 2008a, Alternative indicators for detection and quantification of faecal pollution: Water, v. 39 , p. 39-45.

Ahmed, W., Goonetilleke, A., Powell, D., Chauhan, K., and Gardner, T., 2009a, Comparison of molecular markers to detect fresh sewage in environmental waters: Water Research, v. 43, p. 4908-4917.

Ahmed, W., Goonetilleke, A., Powell, D., and Gardner, T., 2009b, Evaluation of multiple sewage-associated Bacteroides PCR markers for sewage pollution tracking: Water Research, v. 43, p. 4872-4877.

Ahmed, W., Powell, D., Goonetilleke, A., and Gardner, T., 2008b, Detection and source identification of faecal pollution in non-sewered catchment by means of host-specific molecular markers: Water Science and Technology, v. 58, no. 3, p. 579-586.

Anderson, C.R., Johnson, H.A., Caputo, N., Davis, R.E., Torpey, J.W., and Tebo, B.M., 2009, $\mathrm{Mn}$ (II) oxidation is catalyzed by Heme Peroxidases in "Aurantimonas manganoxydans" Strain SI85-9A1 and Erythrobacter sp. Strain SD-21: Applied and Environmental Microbiology, v. 75 , p. $4130-4138$.

Barton, H.A., and Jurado, V., 2007, What's up down there? Microbial diversity in caves: Microbe, v. 2, no. 3, p. 132-138.

Bernhard, A.E., and Field, K.G., 2000a, Identification of nonpoint sources of fecal polluton in coastal waters by using host-specific $16 \mathrm{~S}$ ribosomal DNA genetic markers from fecal anaerobes: Applied and Environmental Microbiology, v. 66, p. 1587-1594. 
Bernhard, A.E., and Field, K.G., 2000b, A PCR assay to discriminate human and ruminant feces on the basis of host differences in Bactreoides-Prevotella genes encoding 16S rRNA: Applied and Environmental Microbiology, v. 66, p. 4571-4574.

Blehert, D.S., Lorch, J.M., Ballmann, A.E., Cryan, P.M., and Meteyer, C.U., 2011, Bat white-nose syndrome in North America: Microbe, v. 6 , p. $267-273$

Bräuer, S.L., Adams, C., Kranzler, K., Murphy, D., Xu, M., Zuber, P., Simon, H.M., Baptista, A.M., and Tebo, B.M., 2011, Culturable Rhodobacter and Shewanella species are abundant in estuarine turbidity maxima of the Columbia River: Environmental Microbiology, v. 13 , no. 3 , p. $589-603$.

Carmichael, M.J., Carmichael, S.K., Santelli, C.M., Strom, A.C., and Bräuer, S.L., 2013, Mn(II)-oxidizing bacteria are abundant and environmentally relevant members of ferromanganese deposits in caves of the upper Tennessee River Basin: Geomicrobiology Journal. DOI: $10.1080 / 01490451.2013 .769651$

Chelius, M.K., Beresford, G., Horton, H., Quirk, M., Selby, G., Simpson, R.T., Horrocks, R., and Moore, J.C., 2009, Impacts of alterations of organic inputs on the bacterial community within the sediments of Wind Cave, South Dakota, USA: International Journal of Speleology, v. 38 , no. 1 , p. $1-10$.

Corstjens, P., de Vrind, J.P.M., Goosen, T., and de Vrind-de Jong, E.W., 1997, Identification and molecular analysis of the Leptothrix discophora SS-1 mof $A$ gene, a gene putatively encoding a manganese-oxidizing protein with copper domains: Geomicrobiology Journal, v. 14 , p. $91-108$.

Denver, J.M., 1989, Effects of agricultural practices and septic-system effluent on the quality of water in the unconfined aquifer in parts of eastern Sussex County, Delaware, Newark, DE, Delaware Geological Survey, University of Delaware.

Dorai-Raj, S., Grady, J.O., and Colleran, E., 2009, Specificity and sensitivity evaluation of novel and existing Bacteroidales and Bifidobacteria-specific PCR assays on feces and sewage samples and their application for microbial source tracking in Ireland: Water Research, v. 43, no. 19 , p. 4980-4988

Duckworth, O.W., and Sposito, G., 2007, Siderophore-promoted dissolution of synthetic and biogenic layer-type Mn oxides: Chemical Geology, v. 242, no. 3-4, p. 497-508.

Engel, A.S., Meisinger, D.B., Porter, M.L., Payn, R.A., Schmid, M., Stern, L.A., Schleifer, K.H., and Lee, N.M., 2010, Linking phylogenetic and functional diversity to nutrient spiraling in microbial mats from Lower Kane Cave (USA): The ISME Journal, v. 4, p. $98-110$.

Felsenstein, J., 2008, PHYLIP (Phylogeny Inference Package) version 3.68, Seattle, WA, University of Washington.

Fischer, T.B., Heaney, P.J., Jang, J.H., Ross, D.E., Brantley, S.L., Post, J.E., and Tien, M., 2008, Continuous time-resolved X-ray diffraction of the biocatalyzed reduction of Mn oxide: American Mineralogist, v. 93, no. 11-12, p. 1929-1932.

Francis, C.A., and Tebo, B.M., 2002, Enzymatic manganese(II) oxidation by metabolically-dormant spores of diverse Bacillus species: Applied and Environmental Microbiology, v. 68, p. 874-880.

Gao, Y., Gibson, N., Burnham, T., and Evanshen, B., 2006, Water chemistry and quality changes in the Rockhouse cave system, Carter County, TN, The Sixteenth Tennessee Water Resources Symposium, 1B-3 - IB-6 $\mathrm{p}$

Geszvain, K., McCarthy, J.K., and Tebo, B.M., 2013, Elimination of manganese (II, III) oxidation in Pseudomonas putida GB-1 by a double knockout of two putative multicopper oxidase genes: Applied and Environmental Microbiology, v. 79, no. 1, p. 357-366.

Gillieson, D.S., 2011, Management of Caves, in van Beynen, P., ed., Karst Management, New York, Springer, p. 141-158.

Goeppert, N., and Goldscheider, N., 2011, Transport and variability of fecal bacteria in carbonate conglomerate aquifers: Ground Water, v. 49 , p. $77-84$.

Goldscheider, N., Hunkeler, D., and Rossi, P., 2006, Review: Microbial biocenoses in pristine aquifers and an assessment of investigative methods: Hydrogeology Journal, v. 14, p. 926-941.

Green, R.T., Painter, S.L., Sun, A., and Worthington, S.R.H., 2006, Groundwater contamination in karst terranes: Water, Air, \& Soil Pollution: Focus, v. 6, no. 1-2, p. 157-170.

Hansel, C.M., Zeiner, C.A., Santelli, C.M., and Webb, S.M., 2012, Mn (II) oxidation by an ascomycete fungus is linked to superoxide production during asexual reproduction: Proceedings of the National Academy of Sciences, v. 109, no. 31, p. 12621-12625.

Hayashi, H., Sakamoto, M., and Benno, Y., 2002, Phylogenetic analysis of the human gut microbiota using $16 \mathrm{~S}$ rDNA clone libraries and strictly anaerobic culture-based methods: Microbiology and Immunology, v. 46 , no. 8 , p. $535-548$.

Hayashi, H., Shibata, K., Sakamoto, M., Tomita, S., and Benno, Y., 2007, Prevotella copri sp. nov. and Prevotella stercorea sp. nov., isolated from human faeces: International Journal of Systematic and Evolutionary Microbiology, v. 57, no. 5, p. 941-946.

Hoagland, A.D., Hill, W.T., and Fulweiler, R.E., 1965, Genesis of the Ordovician zinc deposits in east Tennessee: Economic Geology, v. 60, no. 4 , p. $693-714$.

Horner-Devine, M.C., Leibold, M.A., Smith, V.H., and Bohannan, B.J.M., 2003, Bacterial diversity patterns along a gradient of primary productivity: Ecology Letters, v. 6, p. 613-622.

Ikner, L.A., Toomey, R.S., Nolan, G., Neilson, J.W., Pryor, B.M., and Maier, R.M., 2007, Culturable microbial diversity and the impact of tourism in Kartchner Caverns, Arizona: Microbial Ecology, v. 53, p. $30-42$.

Johnson, G.C., 2002, Water Quality of Springs in the Valley and Ridge Physiographic Province in the Upper Tennessee River Basin, 1997, U.S. Geological Survey Water-Resources Investigations Report 024180.

Johnson, K., Carmichael, M., McDonald, W., Rose, N., Pitchford, J., Windelspecht, M., Karatan, E., and Bräuer, S., 2012, Increased abundance of Gallionella spp., Leptothrix spp. and total bacteria in response to enhanced $\mathrm{Mn}$ and $\mathrm{Fe}$ concentrations in a disturbed southern Appalachian high elevation wetland: Geomicrobiology Journal, v. 29, no. 2, p. 124-138.

Johnson, M., Zaretskaya, I., Raytselis, Y., Merezhuk, Y., McGinnis, S., and Madden, T.L., 2008, NCBI BLAST: a better web interface: Nucleic Acids Research, v. 36, p. W5-W9.

Johnson, T.B., McKay, L.D., Layton, A.C., Jones, S.W., Johnson, G.C., Cashdollar, J.L., Dahling, D.R., Villegas, L.F., Fout, G.S., and Williams, D.E., 2011, Viruses and bacteria in karst and fractured rock aquifers in east Tennessee, USA: Ground Water, v. 49, no. 1, p. $98-110$.

Johnston, M.D., Muench, B.A., Banks, E.D., and Barton, H.A., 2012, Human urine in Lechuguilla Cave: the microbiological impact and potential for bioremediation: Journal of Cave and Karst Studies, v. 74, no. 3, p. 278-291.

Ju-Yong, J., Park, H.-D., Lee, K.-H., Hwang, J.-H., and Ka, J.-O., 2010, Quantitative analysis of human- and cow-specific 16S rRNA gene markers for assessment of fecal pollution in river waters by Real-Time PCR: Journal of Microbiology and Biotechnology, v. 20, p. 245-253.

Krumbein, W.E., and Altmann, H.J., 1973, A new method for the detection and enumeration of manganese oxidizing and reducing microorganisms: Helgolander Wissenschaftlichen Untersuchungen, v. 25 , p. $347-356$.

Lamendella, R., Santo Domingo, J.W., Oerther, D.B., Vogel, J.R., and Stoeckel, D.M., 2007, Assessment of fecal pollution sources in a small northern-plains watershed using PCR and phylogenetic analyses of Bacteroidetes 16S rRNA gene: FEMS Microbiology Ecology, v. 59, no. 3, p. 651-660.

Lamendella, R., Santo Domingo, J.W., Yannarell, A.C., Ghosh, S., Di Giovanni, G., Mackie, R.I., and Oerther, D.B., 2009, Evaluation of swine-specific PCR assays used for fecal source tracking and analysis of molecular diversity of swine-specific "Bacteroidales" populations: Applied and Environmental Microbiology, v. 75 , no. 18, p. $5787-$ 5796.

Learman, D.R., Wankel, S.D., Webb, S.M., Martinez, N., Madden, A.S., and Hansel, C.M., 2011, Coupled biotic-abiotic Mn(II) oxidation pathway mediates the formation and structural evolution of biogenic Mn oxides, Geochimica et Cosmochimica Acta.

Ley, R.E., Backheld, R., Turnbaugh, P.J., Lozupone, C.A., Knight, R.A., and Gordon, J.I., 2005, Obesity alters gut microbial ecology: Proceedings of the National Academy of Sciences, v. 102, p. 11070-11075.

Ley, R.E., Peterson, D.A., and Gordon, J.I., 2006, Ecological and evolutionary forces shaping microbial diversity in the human intestine: Cell, v. 124 , no. 4 , p. $837-848$.

Liers, C., Arnstadt, T., Ullrich, R., and Hofrichter, M., 2011, Patterns of lignin degradation and oxidative enzyme secretion by different wood- 
and litter-colonizing basidiomycetes and ascomycetes grown on beech-wood: FEMS Microbiology Ecology, v. 78, no. 1, p. 91-102.

Ludwig, W., Strunk, O., Westram, R., Richter, L., Meier, H., Yadhukumar, Buchner, A., Lai, T., Steppi, S., Jobb, G., Forster, W., Brettske, I., Gerber, S., Ginhart, A.W., Gross, O., Grumann, S., Hermann, S., Jost, R., Konig, A., Liss, T., Lussmann, R., May, M., Nonhoff, B., Reichel, B., Strehlow, R., Stamatakis, A., Stuckmann, N., Vilbig, A., Lenke, M., Ludwig, T., Bode, A., and Schleifer, K.H., 2004, ARB: a software environment for sequence data: Nucleic Acids Research, v. 32, no. 4, p. 1363-1371.

Luther, G.W., 2010, The role of one-and two-electron transfer reactions in forming thermodynamically unstable intermediates as barriers in multielectron redox reactions: Aquatic Geochemistry, v. 16, no. 3, p. 395-420.

Macalady, J.L., Dattagupta, S., Schaperdoth, I., Jones, D.S., Druschel, G.K., and Eastman, D., 2008, Niche differentiation among sulfuroxidizing bacterial populations in cave waters: The ISME Journal, v. 2 , p. $590-601$.

Mikell, A.T., Smith, C.L., and Richardson, J.C., 1996, Evaluation of media and techniques to enumerate heterotrophic microbes from karst and sand aquifer springs: Microbial Ecology, v. 31, no. 2, p. 115-124.

Miller, J., and Hiskey, J., 1972, Electrokinetic behavior of fluorite as influenced by surface carbonation: Journal of Colloid and Interface Science, v. 41, no. 3, p. 567-573.

Minnesota Pollution Control Agency, 1999, Effects of Septic Systems on Ground Water Quality - Baxter, Minnesota, St. Paul, Ground Water Monitoring and Assessment Program, Ground Water and Toxics Monitoring Unit, Environmental Monitoring and Analysis Section, Environmental Outcomes Division, $37 \mathrm{p}$.

Mulec, J., Kristufek, V., and Chronakova, A., 2012, Comparative microbial sampling from eutrophic caves in Slovenia and Slovakia using RIDA(R) COUNT test kits: International Journal of Speleology, v. 41 , p. $1-8$.

Northup, D.E., 2011, Managing microbial communities in caves, in van Beynen, P., ed., Karst Management, New York, Springer, p. 225-240.

Northup, D.E., Barns, S.M., Yu, L.E., Spilde, M.N., Schelble, R.T., Dano, K.E., Crossey, L.J., Connolly, C.A., Boston, P.J., Natvig, D.O., and Dahm, C.N., 2003, Diverse microbial communities inhabiting ferromanganese deposits in Lechuguilla and Spider Caves: Environmental Microbiology, v. 5, no. 11, p. 1071-1086.

Northup, D.E., and Lavoie, K.H., 2001, Geomicrobiology of caves: A review: Geomicrobiology Journal, v. 18, no. 3, p. 199-222.

Porter, M.L., 2007, Subterranean biogeography: what have we learned from molecular techniques?: Journal of Cave and Karst Studies, v. 69, p. $179-186$.

Portillo, M.C., and Gonzalez, J.M., 2010, Differential effects of distinct bacterial biofilms in a cave environment: Current Topics in Microbiology, v. 60, p. 435-438.

Portillo, M.C., Porca, E., Cuezva, S., Canaveras, C., Sanchez-Moral, S., and Gonzalez, J.M., 2009, Is the availability of different nutrients a critical factor for the impact of bacteria on subterraneous carbon budgets?: Naturwissenschaften, v. 96, p. 1035-1042.

Post, J.E., 1999, Manganese oxide minerals: crystal structures and economic and environmental significance: Proceedings of the National Academy of Sciences USA, v. 96, p. 3447-3454.

Potter, R.M., and Rossman, G.R., 1979, The tetravalent manganese oxides: identification, hydration, and structural relationships by infrared spectroscopy: American Mineralogist, v. 64, p. 1199-1218.

Pruesse, E., Quast, C., Knittel, K., Fuchs, B.M., Ludwig, W., Peplies, J., and Glockner, F.O., 2007, SILVA: a comprehensive online resource for quality checked and aligned ribosomal RNA sequence data compatible with ARB: Nucleic Acids Research, v. 35, no. 21, p. 7188-7196.
Reischer, G.H., Kasper, D.C., Steinborn, R., Farnleitner, A.H., and Mach, R.L., 2007, A quantitative real-time PCR assay for the highly sensitive and specific detection of human faecal influence in spring water from a large alpine catchment area: Letters in Applied Microbiology, v. 44, p. 351-356.

Robertson, W., Schiff, S., and Ptacek, C., 1998, Review of phosphate mobility and persistence in 10 septic system plumes: Ground Water, v. 36 , no. 6 , p. $1000-1010$.

Roslev, P., and Bukh, A.S., 2011, State of the art molecular markers for fecal pollution source tracking in water: Applied Microbiology and Biotechnology, v. 89, p. 1341-1355.

Rusterholtz, K.J., and Mallory, L.M., 1994, Density, activity, and diversity of bacteria indigenous to a karstic aquifer: Microbial Ecology, v. 28, no. 1, p. 79-99.

Santelli, C.M., Webb, S.M., Dohnalkova, A.C., and Hansel, C.M., 2011, Diversity of $\mathrm{Mn}$ oxides produced by $\mathrm{Mn}(\mathrm{II})$-oxidizing fungi: Geochimica et Cosmochimica Acta, v. 75, no. 10, p. 2762-2776.

Schloss, P.D., and Handelsman, J., 2005, Introducing DOTUR, a computer program for defining operational taxonomic units and estimating species richness: Applied and Environmental Microbiology, v. 71, p. 1501-1506.

Shabarova, T., and Pernthaler, J., 2010, Karst pools in subsurface environments: collectors of microbial diversity or temporary residence between habitat types: Environmental Microbiology, v. 12, p. 10611074.

Shah, H.N., and Collins, D.M., 1990, NOTES: Prevotella, a new genus to include Bacteroides melaninogenicus and related species formerly classified in the genus Bacteroides: International Journal of Systematic Bacteriology, v. 40, no. 2, p. 205-208.

Simon, K.S., and Buikema, A.L., 1997, Effects of organic pollution on an Appalachian cave: Changes in macroinvertebrate populations and food supplies: American Midland Naturalist, v. 138, no. 2, p. $387-401$.

Simpson, J.M., Santo Domingo, J.W., and Reasoner, D.J., 2004, Assessment of equine fecal contamination: the search for alternative bacterial source-tracking targets: FEMS Microbiology Ecology, v. 47, no. 1, p. $65-75$.

Spiro, T.G., Bargar, J.R., Sposito, G., and Tebo, B.M., 2010, Bacteriogenic manganese oxides: Accounts of Chemical Research, v. 43 , no. 1 , p. $2-9$.

Ueki, A., Akasaka, H., Satoh, A., Suzuki, D., and Ueki, K., 2007, Prevotella paludivivens sp. nov., a novel strictly anaerobic, Gramnegative, hemicellulose-decomposing bacterium isolated from plant residue and rice roots in irrigated rice-field soil: International Journal of Systematic and Evolutionary Microbiology, v. 57, no. 8, p. $1803-1809$.

van Beynen, P., and Townsend, K., 2005, A disturbance index for karst environments: Environmental Management, v. 36, p. 101-116.

Vesper, D.J., Loop, C.M., and White, W.B., 2001, Contaminant transport in karst aquifers: Theoretical and Applied Karstology, v. 13, p. 63-73.

Walker, A., Sanderson, J., Churcher, C., Parkes, G., Hudspith, B., Rayment, N., Brostoff, J., Parkhill, J., Dougan, G., and Petrovska, L., 2011, High-throughput clone library analysis of the mucosa-associated microbiota reveals dysbiosis and differences between inflamed and non-inflamed regions of the intestine in inflammatory bowel disease: BMC Microbiology, v. 11, no. 1, 7 p.

Worthington, S.R.H., 2011, Management of carbonate aquifers, in van Beynen, P., ed., Karst Management, New York, Springer, p. 243-261.

Zhu, M., Ginder-Vogel, M., Parikh, S.J., Feng, X.-H., and Sparks, D.L., 2010, Cation Effects on the Layer Structure of Biogenic Mn-Oxides: Environmental Science and Technology, v. 44, no. 12, p. 4465-4471. 